\title{
Geomorphic and pedogenic evolution in coastal sediments, central California
}

\author{
L.E. Moody R.C. Graham \\ Department of Soil and Environmental Sciences, University of California, Riverside, CA 92521-0424, USA
}

\begin{abstract}
Studies of soil chronosequences on marine terraces facilitate the use of terraces for tectonic and paleoclimatic interpretation. However, many areas on the California coast have received substantial eolian deposits after pedogenesis began, so do not qualify as chronosequences. These areas are worthy of study because they are widespread coastal landscape features, and they enable us to interpret pedogenic and geomorphic processes in sandy regolith. The objective of this study was to use soil and deep regolith morphology and chemistry to interpret pedogenic and geomorphic evolution on a sequence of four marine terraces, San Luis Obispo County, California. The terraces are numbered 1, 2,3 , and 4, from oldest to youngest. The eroded terrace platforms have been tentatively dated at 560 , 420 or 480,320 , and $120 \mathrm{ka}$, respectively. The sand deposits on each platform may be considerably younger. The amount of land surface dissection and the depth of stream incision increase with increasing terrace age and elevation. Morphological features suggest that the soils (Xeropsamments on Terrace 4, Haploxerolls on Terrace 3 ) on the two youngest terraces are well drained, and their morphological development is typical of soils in eolian sand deposits. Morphological and chemical features of the basal regolith contrast with those of the soils. Clay, Fe oxides, and opaline silica were deposited by groundwater flow above the bedrock platform. Above the shoreline angle, where the deep regolith receives additional groundwater from higher terraces, redoximorphic features have developed. Gray mottles are larger, more common, and more distinct in the basal regolith of progressively older terraces. Erosion has removed much of the overburden on Terraces 2 and 1, and soils (Epiaquolls on Terrace 2, Epiaqualfs on Terrace 1) have developed in what was once deep regolith. The landscape, soils, and deep regolith show an evolution of processes, whereby the path and direction of water movement through the regolith is controlled first by terrace morphology and stratigraphy, then by the development of pedogenic features in the soil and deep regolith, and by terrace dissection.
\end{abstract}

\section{Introduction}

Marine terraces are records of the interaction of worldwide sea level fluctuations, tectonic activity, and coastal erosion and sedimentation, throughout the late Quaternary. Terrace 
platforms are erosional features formed during sea level transgressions induced by melting of continental ice caps, and the platforms generally are covered by marine and nonmarine sediments (Kern, 1977). The landform of a terrace platform with its overlying sediments is broad and bench-like, elongate parallel to the shoreline. In this paper, the term "terrace" refers to this bench-like landform (Bates and Jackson, 1984).

Marine terraces have been used for evaluating tectonic movement (Bradley and Griggs, 1976; Kern, 1977; Lajoie, 1986; Bishop, 1991) and eustatic sea level changes (Birkeland, 1972; Muhs, 1983; Muhs, 1992). To facilitate these uses, soils on sequences of marine terraces have been used as chronosequences, for relative dating and coastal terrace correlation (Muhs, 1982; Merritts et al., 1991; Bockheim et al., 1992) and for studying rates and processes of geochemical and pedogenic changes (Aniku and Singer, 1990; Merritts et al., 1991; Bockheim et al., 1992).

There are many areas on the California coast which do not meet the criteria for chronosequences. Numerous eolian sand deposits are found where headlands extend outward and intercept sand being transported south by littoral drift (Cooper, 1967; Orme and Tchakerian, 1986) (Fig. 1). These eolian deposits are not acceptable for chronosequence studies, because old sand deposits are easily redistributed by wind, and younger sands can be blown up onto and mixed in with older deposits. Both occurrences have a rejuvenating effect on soils. Also, the complex stratigraphy of onlapping sand deposits can be confusing, and may make even relative dating uncertain. Yet because of their common occurrence, eolian deposits are significant in the coastal geologic record. Extensive eolian sand deposits are also climatic records, being deposited inland during eustatic sea level low stands, when offshore sand deposits were exposed to sorting and distribution by wind (Muhs, 1983, 1992; Orme and Tchakerian, 1986).

High stands of sea level cut platforms into Miocene siliceous shale on the central California coast, north of Point Buchon (Fig. 2). The platforms are overlain by thick beach and eolian sand deposits. Examination of soil profiles and stratigraphic sections through sediments on the youngest of these terraces showed substantial differences in morphology and chemistry of deep regolith and soils. Morphological and chemical features depend on the movement of water in the regolith (Moody and Graham, 1994). In this paper, we relate soil and deep regolith evolution to changes in geomorphology and groundwater hydrology of the terrace sequence. In addition to having geologic and pedogenic significance, study of soil and lanciscape evolution is relevant to coastal erosion problems. Furthermore, interpretations of water movement through sandy sediments are relevant to problems of environmental contaminant transport, especially in light of increasing development pressure for residential, industrial, and agricultural uses in coastal areas.

\section{Study area description}

This study addressed eolian and beach sand deposits on a sequence of Pleistocene wavecut terraces, in the Point Buchon area, San Luis Obispo, California (Fig. 1). Winds have been dominantly from the northwest throughout the Quaternary (Cooper, 1967; Orme and Tchakerian, 1986). Average annual precipitation is $460 \mathrm{~mm}$ per year, most of which occurs November through April. Average annual temperature is $15^{\circ} \mathrm{C}$ (Ernstrom, 1984). Vegeta- 


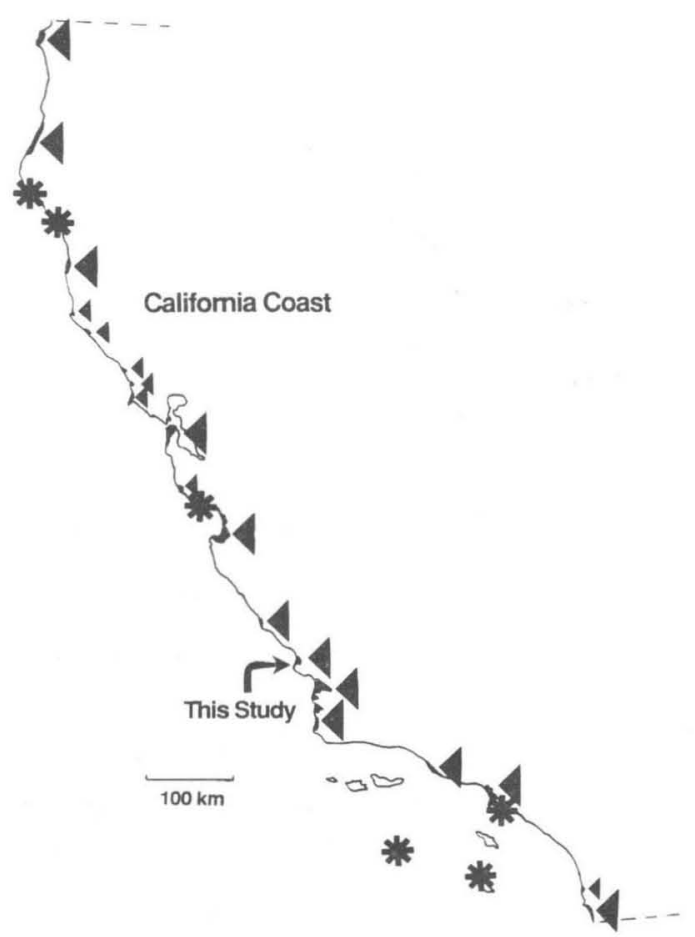

Fig. 1. Location map, California coast. Arrows point to dune fields (solid black on map, from Cooper, 1967). Stars show locations of chronosequence studies (from north to south, on mainland: Merritts et al., 1991; Jenny, 1980; Aniku and Singer, 1990; Channel Island studies by Muhs, 1982, 1992).

tion on the youngest terrace consists of shrubs, dominantly Morro manzanita (Arctostaphylos morroensis Wiesl. and B. Schreiber) and buck brush (Ceanothus cuneatus Nutt.), and annual grasses. The next two terraces support annual grasses and shrubs, dominantly coyote brush (Baccharis pilularis DC.), California sagebrush (Artemesia californica Less.), and poison oak (Toxicodendron diversilobum Torrey and A. Gray). Vegetation on the oldest terrace consists mostly of the shrubs Morro manzanita and chamise (Adenostoma fasciculatum Hook. and Arn.).

\subsection{Geologic setting}

The study area is within the Pismo syncline structural province, a broad synclinorium with local faulting, especially high angle reverse and thrust faults (Hall et al., 1979; Cleveland, 1978). The Pismo syncline is bounded on the north by the Edna fault zone, which has a NW-SE trend, and passes offshore through the south end of Morro Bay, and on the south by the San Miguelito Fault, which also has a NW-SE trend, and passes offshore about 5 km south of Point Buchon (Fig. 2).

Cleveland (1978) identified and mapped four terraces in the Point Buchon area, and designated them by number, from Terrace 1 (the youngest, lowest emergent terrace) through Terrace 4 (the oldest). He mapped Terraces 1 and 2 south of Islay Creek, but to the north, 


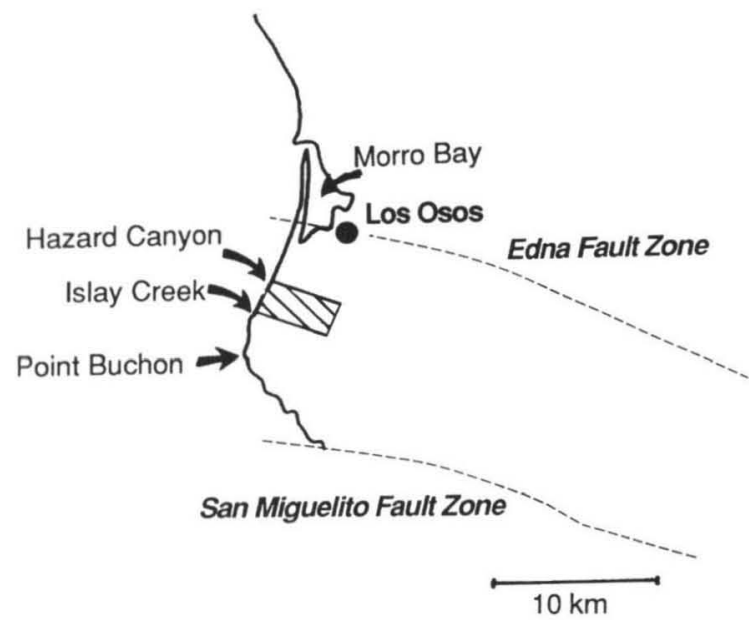

Fig. 2. Geographic and tectonic setting of study area. The study area is cross-hatched.

he noted that these two terraces become indistinguishable, possibly due to varying rates of uplift from south to north, and he combined them into Terrace 1-2. Cleveland (1978) did not record the presence of the highest terrace. In this paper, we reverse Cleveland's system, designating the oldest terrace as Terrace 1, and the youngest as Terrace 4 (Table 1; Fig. 3).

\subsection{Terrace morphology and stratigraphy}

A cross section of a terrace such as in the Point Buchon area illustrates terrace morphology (Fig. 4; terms for terrace morphology from Kern, 1977). The shoreline angle is the interTable 1

Estimated ages of terraces and associated sand deposits

\begin{tabular}{|c|c|c|c|c|}
\hline Terrace & $\begin{array}{l}\text { Terrace age } \\
\text { (ka) }\end{array}$ & Method & $\begin{array}{l}\text { Possible sand deposit ages } \\
\text { (ka) }\end{array}$ & Method of dating \\
\hline $4^{a}$ & 120 & $\begin{array}{l}\text { Correlation with last major } \\
\text { interglacial }\end{array}$ & $\begin{array}{l}\text { Holocene: } 1 \\
\text { Pleistocene: } 12-27 \text { or } 48\end{array}$ & $\begin{array}{l}{ }^{14} \mathrm{C} \text { date, marine shell } \\
\text { fragment } \\
\text { Soil morphology, compared } \\
\text { with Muhs (1983) and } \\
\text { Torrent et al. (1980) }\end{array}$ \\
\hline 3 & 320 & $\begin{array}{l}\text { Correlation with sea level } \\
\text { high stands }{ }^{\text {b }}\end{array}$ & 140,180 , and/or 280 & $\begin{array}{l}\text { Correlation with sea level } \\
\text { low stands }{ }^{c}\end{array}$ \\
\hline 2 & 420 or 480 & $\begin{array}{l}\text { Correlation with sea level } \\
\text { high stands }^{\text {b }}\end{array}$ & 340 and/or 460 & $\begin{array}{l}\text { Correlation with sea level } \\
\text { low stands }{ }^{c}\end{array}$ \\
\hline 1 & 560 & $\begin{array}{l}\text { Correlation with sea level } \\
\text { high stands }{ }^{\mathrm{b}}\end{array}$ & 460 and/or 520 & $\begin{array}{l}\text { Correlation with sea level } \\
\text { low stands }{ }^{c}\end{array}$ \\
\hline
\end{tabular}

'This numbering order reverses that of Cleveland (1978).

${ }^{b}$ Using Fig. 5 and the methods of Merritts and Bull (1989).

'Using Fig. 5, and assuming that major eolian deposition cannot occur on uplifting terraces greater than $90 \mathrm{~m}$ above sea level. 


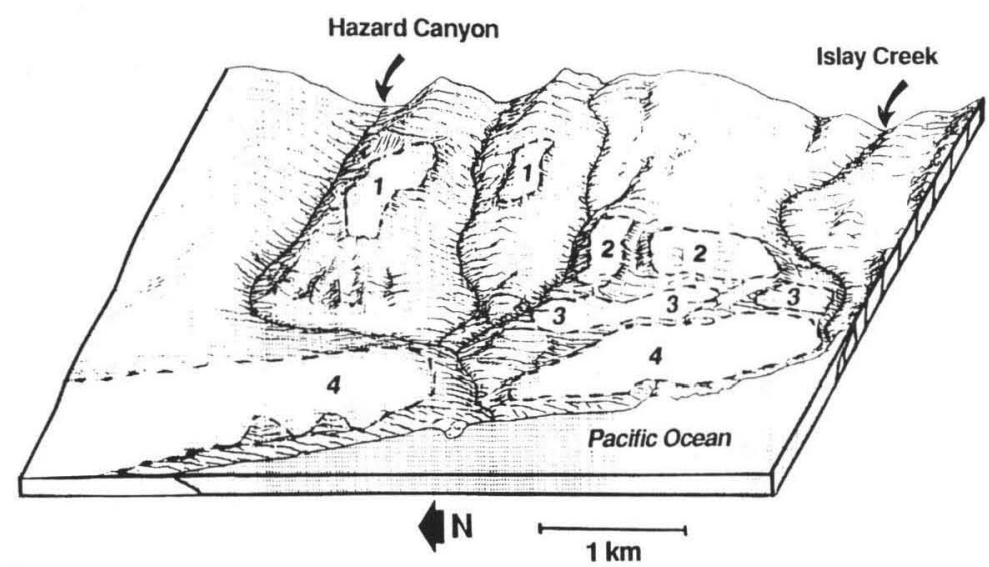

Fig. 3. Block diagram of study area, showing terrace topographic surfaces. Elevation of Terrace 1 is about $200 \mathrm{~m}$.

section of the sea cliff and bedrock platform. Typically, a layer of littoral gravels and cobbles overlies the bedrock platform, and is in turn overlain by a thick sequence of beach and eolian sand deposits. The route of water movement shown in Fig. 4 was based on observations of seasonal springs exfiltrating at the seaward edges of Terraces 4,3 , and 2 , and at portions of the shoreline angle of Terrace 3 which had been exposed by erosion. Water infiltrates through surface horizons and moves downward to the lower limit of the wetting front. When water percolates through the overburden to the basal sediments, a perched water table develops above the bedrock platform, and water moves seaward due to the slope of the bedrock platform (Moody and Graham, 1994).

In order to study rates of pedogenic and geomorphic processes, it is necessary to know the ages of the terraces and their deposits. Terrace and sediment ages in this sequence are problematic, because of the lack of datable material and difficulty in correlating with terraces in different structural provinces. Cleveland (1978) estimated the age of the youngest terrace to be 80 to $105 \mathrm{ka}$, based on fossil evidence and local uplift rates, but without specifying the dating method used. We judged that this terrace most likely correlates with a major sea level high stand at $120 \mathrm{ka}$. Gravel and sand on the oldest terrace has been tentatively placed within the upper Orcutt Sand (Orme and Tchakerian, 1986), which is late Pleistocene in age (Woodring and Bramlette, 1950). A marine terrace platform is abraded by wave erosion during rising sea level, thus the shoreline angle represents the elevation of the sea level high stand. The elevation of Terrace 3 was measured where the shoreline angle was partially exposed by erosion of overlying sediments. We estimated the elevations of the buried

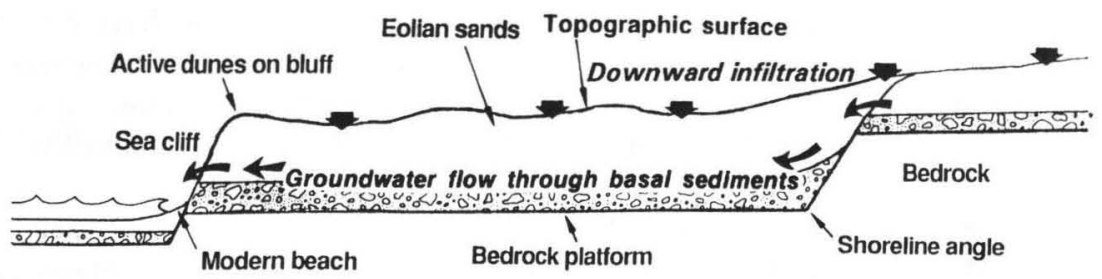

Fig. 4. General cross section of terrace morphology and stratigraphy. Bold arrows indicate direction of water movement through sandy regolith. Terrace morphology terminology from Kern (1977). 


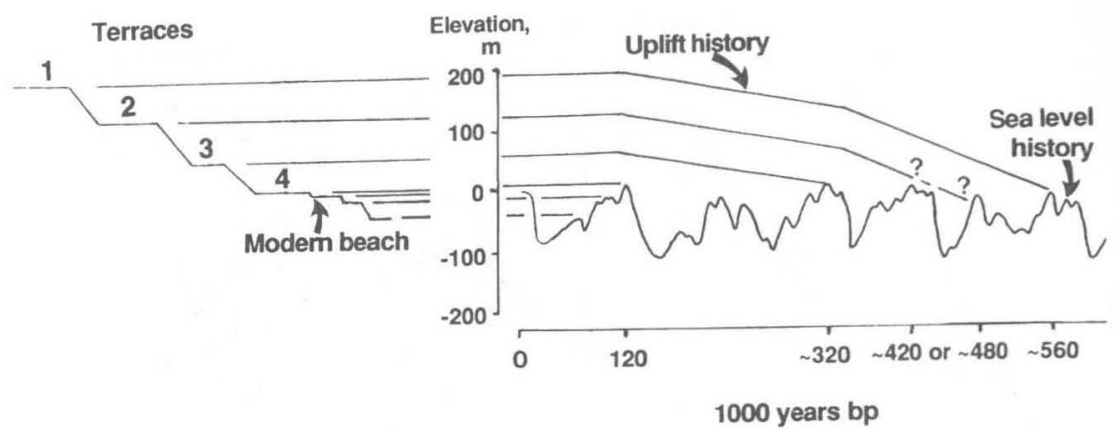

Fig. 5. Sea level history curve (Muhs, 1992) and uplift history curves, showing correlation of sea level high stands with terrace bedrock platforms, using method of Merritts and Bull (1989).

shoreline angles of Terraces 4, 2, and 1. Using the $120 \mathrm{ka}$ age for Terrace 4, we correlated the older terraces with major eustatic sea level high stands using the method of Merritts and Bull (1989), and estimated terrace ages at about 320 ka for Terrace 3, 420 or 480 ka for Terrace 2, and $560 \mathrm{ka}$ for Terrace 1 (Fig. 5). A major interglacial at about 560 ka could correlate with the late Pleistocene Orcutt Sand. Two submerged terraces, at -20 and -40 $\mathrm{m}$, have been reported (Thomas J. Rice, Soil Science Department, California Polytechnic State University, San Luis Obispo, pers. commun., 1993), and correlate with sea level high stands at about 70 and $100 \mathrm{ka}$ (Fig. 5). These terraces are now submerged because the sea level high stands that abraded them were lower than the present sea level high stand (at 0 m elevation, Fig. 5), and because there appears to have been no uplift in this study area for the past 120,000 years, as shown by the uplift history curves (Fig. 5). Terrace ages reported here are estimates and other interpretations are possible, by using this sea level history curve, or by using any of several sea level curves in the recent literature (Matthews, 1990; Emery and Aubrey, 1991; Hallam, 1992).

The ages of major eolian deposition must correspond to eustatic sea level low stands, during which offshore sands are exposed to sorting and distribution by wind (Muhs, 1983, 1992). Muhs (1983) dated a thick eolianite at between 12 and $27 \mathrm{ka}$, overlying marine terrace sediments dated at $80 \mathrm{ka}$ on San Clemente Island, southern California. Near San Diego, an extensive sand deposit with textural lamellae was dated at $48 \mathrm{ka}$ (Torrent et al., 1980). The degree of pedogenic development (i.e., color, thickness, and clay content of lamellae) of the San Clemente and San Diego deposits is similar to an eolianite on Terrace 4 of this study, suggesting the sand deposits on Terrace 4 may be within the age range of these eolianites, between 12 and $48 \mathrm{ka}$ (Table 1).

Fig. 5 shows that there are several sea level low stands, thus several possible episodes of eolian deposition, following each sea level high stand. Wind tunnel studies have shown that wind velocity on bluff tops at Lake Superior can be 1.7 times faster than on the upwind side of the bluffs (Marsh, 1990). This provides carrying power sufficient to blow sand a considerable vertical distance. Onshore winds from Lake Superior carry sand up to $90 \mathrm{~m}$ from the base of coastal bluffs to bluff tops (Marsh, 1990).

In the Point Buchon area, eolian deposition may have continued as long as a sand source existed and until the terrace topographic surfaces were lifted to a considerable elevation. With tectonic uplift, the former shoreline not only has been removed vertically from the sand source, but also has moved inland, as the coastline progressively has shifted seaward 
by emergence of new lands, formerly submerged. If vegetative cover is sparse or absent, the surfaces of older sand deposits can be reworked by winds, even during sea level high stands when the source of new sand has been cut off. Active and recently active dunes line the top of the current coastal bluffs, and a marine shell fragment found in the upper $0.5 \mathrm{~m}$ of Terrace 4 was dated by ${ }^{14} \mathrm{C}$ at $0.98 \pm 0.06 \mathrm{ka}$.

In summary, although the ages of the terrace platforms may be estimated, the ages of eolian and beach sand deposits on the terrace platforms are more in doubt, and can only be said to be younger than the terrace platforms. Estimates of terrace platform and sand deposit ages are summarized in Table 1 .

\section{Methods}

\subsection{Field description and sampling}

Auger borings on all terraces were used to determine locations for representative pedons, which were described and sampled in hand-excavated pits according to standard methods (Soil Survey Division Staff, 1993; Soil Conservation Service, 1984), and classified according to soil taxonomy (Soil Survey Staff, 1992). Deep regolith was described and sampled from natural exposures in stream cuts and gullies, sea cliffs, blowouts, and landslide scars, using standard stratigraphic descriptive techniques (Blatt et al., 1980), supplemented by soil descriptive methods. The sides of these exposures were excavated 0.25 to $1 \mathrm{~m}$ to reveal fresh regolith material.

\subsection{Laboratory analyses}

Particle size distribution was determined by sieving and pipette after removal of organic matter by $\mathrm{H}_{2} \mathrm{O}_{2}$ digestion ( $\mathrm{Gee}$ and Bauder, 1986). Selective dissolution techniques used to determine $\mathrm{Fe}, \mathrm{Al}$, and $\mathrm{Si}$ in the whole soil were sodium pyrophosphate $\left(\mathrm{Fe}_{\mathrm{p}}\right.$ and $\mathrm{Al}_{\mathrm{p}}$ ) (Bascomb, 1968), acid ammonium oxalate in the dark $\left(\mathrm{Fe}_{\mathrm{o}}, \mathrm{Al}_{\mathrm{o}}\right.$, and $\mathrm{Si}_{\mathrm{o}}$ ) (Jackson et al., 1986), sodium citrate-bicarbonate-dithionite $\left(\mathrm{Fe}_{\mathrm{d}}\right.$ and $\left.\mathrm{Al}_{\mathrm{d}}\right)$ (Jackson et al., 1986), and Tiron $\left(\mathrm{Si}_{\mathrm{T}}\right)$ (Kodama and Ross, 1991). Iron, $\mathrm{Al}$, and $\mathrm{Si}$ were determined by atomic absorption spectrophotometry and calculated on a soil dry weight basis. The $\mathrm{pH}$ of soil and regolith material was determined in a 1:1 soil:water paste (McLean, 1982). Micromorphology of selected pedogenic features from undisturbed samples was described using polarized light microscopy. Descriptive terminology follows Brewer (1976). Radiocarbon dates on charcoal and marine shell fragments were obtained using accelerator mass spectrometry.

\section{Results and discussion}

\subsection{Parent material}

Modern beach and eolian deposits are stratified, well-sorted fine sands, containing less than $1 \%$ clay and silt, with 2.5 Y $4 / 4$ to 10 YR $4 / 4$ moist colors. From petrographic analyses, 
Selected morphological features of representative pedons, Terraces 4 and 3

\begin{tabular}{|c|c|c|c|c|c|c|c|c|c|c|c|}
\hline \multirow[t]{2}{*}{ Horizon } & \multirow{2}{*}{$\begin{array}{l}\text { Depth } \\
\text { (m) }\end{array}$} & \multirow{2}{*}{$\begin{array}{l}\text { Moist } \\
\text { color }\end{array}$} & \multicolumn{3}{|l|}{$\%(w / w)$} & \multirow[t]{2}{*}{ Structure } & \multirow{2}{*}{$\begin{array}{l}\text { Clay } \\
\text { films }\end{array}$} & & \multicolumn{3}{|c|}{ Lamellae } \\
\hline & & & Sand Silt & Clay & FC:TC & & & Lamellae & Color & $\%$ Clay & FC:TC \\
\hline
\end{tabular}

CCT-1, representative pedon, Holocene soil, Terrace 4 (mixed, thermic Argic Xeropsamment)

\begin{tabular}{|c|c|c|c|c|c|c|c|c|c|c|c|c|}
\hline A 1 & $0-0.12$ & $10 \mathrm{YR} 3 / 3$ & 98.1 & 1.3 & 0.7 & 0.2 & $1 \operatorname{cog} r$ & 0 & 0 & - & - & - \\
\hline A2 & $0.12-0.22$ & $10 \mathrm{YR} 3 / 4$ & 96.9 & 1.4 & 1.7 & 0.5 & $1 \mathrm{fsbk}$ & 0 & 0 & - & - & - \\
\hline A3 & $0.22-0.43$ & $10 \mathrm{YR} 4 / 4$ & 97.8 & 0.7 & 1.4 & 0.2 & $\mathrm{~m}$ & 0 & 0 & - & - & - \\
\hline Bwl 1 & $0.43-1.07$ & $10 \mathrm{YR} 5 / 6$ & 96.6 & 1.0 & 2.4 & 0.6 & $\mathrm{~m}$ & 0 & 0 & - & - & - \\
\hline Bw2 & $1.07-1.29$ & $10 \mathrm{YR} 5 / 6$ & 98.4 & 0.9 & 0.8 & 0 & $\mathrm{~m}$ & 0 & 0 & - & - & - \\
\hline $\mathrm{Bt}$ & $1.29-2.01$ & 10YR 5/6 & 96.0 & 1.8 & 2.2 & 0.7 & $\mathrm{~m}$ & co \& br & flf & 7.5 YR $4 / 6$ & 3.0 & 0.7 \\
\hline
\end{tabular}

BNT-6, representative pedon, Terrace 3 (sandy, mixed, thermic Typic Haploxeroll)

\begin{tabular}{|c|c|c|c|c|c|c|c|c|c|c|c|c|}
\hline Al & $0-0.31$ & $10 \mathrm{YR} 3 / 3$ & 88.9 & 3.6 & 7.5 & 0.4 & $1 \mathrm{mgr}$ & 0 & 0 & - & - & - \\
\hline $\mathrm{A} 2$ & $0.31-0.60$ & $10 \mathrm{YR} 3 / 3$ & 86.7 & 6.0 & 7.2 & 0.4 & $1 \mathrm{fsbk}$ & 0 & 0 & - & - & - \\
\hline A3 & $0.60-0.99$ & $10 \mathrm{YR} 3 / 3$ & 86.4 & 6.8 & 6.9 & 0.6 & $\mathrm{~m}$ & 0 & 0 & - & - & - \\
\hline $\mathrm{Bw}$ & $0.99-1.28$ & $7.5 Y R 3 / 4$ & 87.0 & 7.2 & 5.7 & 0.5 & $\mathrm{~m}$ & 0 & 0 & - & - & - \\
\hline Btl & $1.28-1.47$ & $7.5 Y R 3 / 4$ & 88.4 & 6.6 & 5.0 & 0.5 & $\mathrm{~m}$ & co \& br & flf & $7.5 Y R 3 / 4$ & nd & nd \\
\hline $\mathrm{Bt} 2$ & $1.47-1.76$ & $10 \mathrm{YR} 4 / 4$ & 91.0 & 4.7 & 4.3 & 0.5 & $\mathrm{~m}$ & co \& br & cld & $7.5 Y R 3 / 4$ & 13.2 & 0.6 \\
\hline $\mathrm{Bt} 3$ & $1.76-1.93$ & $10 Y R 4 / 4$ & 90.6 & 3.7 & 5.6 & 0.4 & $\mathrm{~m}$ & co \& br & fld & 7.5 YR $3 / 4$ & 13.3 & 0.7 \\
\hline $\mathrm{Bt} 4$ & $1.93-2.36$ & $10 \mathrm{YR} 4 / 4$ & 80.9 & 4.0 & 5.1 & 0.6 & $\mathrm{~m}$ & nd & present & $7.5 Y R 3 / 4$ & nd & nd \\
\hline
\end{tabular}

the fine sand fractions of modern beach and dune sands are about $40 \%$ quartz, $20 \%$ feldspars, $15 \%$ chert fragments, $10 \%$ siliceous shale fragments (opal-A, opal-CT, and chert), $15 \%$ mafic minerals (amphibole, pyroxene, serpentine, and chlorite), and $<2 \%$ accessory minerals. Accessory minerals include micas, magnetite, chromite, garnet, and calcium carbonate shell fragments.

\subsection{Landscape development}

The surface of the youngest emergent terrace, Terrace 4, is a complex of Holocene depositional and erosional surfaces. The surface has been shaped by wind into dunes and blowouts, and by water carving gullies into the surface. Most gullies follow an E-W trend, as do the major streams. Blowouts are roughly circular, shallow (generally $<2 \mathrm{~m}$ ) depressions in unconsolidated Holocene sands that blanket the surface of Terrace 4, sometimes with sand piled on the downwind side of the blowout scar. Soils on blowout floors are often noticeably redder than soils at the edges, suggesting that the depth of the blowouts may be controlled by the depths of Bw horizons in the Holocene soil, where sand grains are coated and weakly cemented by Fe oxides (Pedon CCT-1, Table 2). Most active dunes are parabolic. Some coppice dunes have formed where vegetation has trapped blowing sand.

Terrace 3 is narrower than the other terraces (Fig. 3). The particle size distribution, in which the modal sand size is fine sand ( 0.106 to $0.25 \mathrm{~mm}$ diameter; data not shown) suggests the Terrace 3 sand deposits were eolian in origin (Blatt et al., 1980). If it is assumed that these sands were deposited as dunes, as on Terrace 4, then dune morphology has been completely subdued on the Terrace 3 surface. Surfaces are flat to slightly undu- 
lating, and appear to be erosional, sometimes capped with Holocene sand deposits. Stream incision is substantial in the dissection of Terrace 3. Gullies are deeply incised, some deeply enough to intersect the basal regolith.

The topographic surfaces of Terrace 2 remnants slope gently seaward and toward streams, but terrace remnants still retain much of the bench-like form. Approximately $20 \%$ of the terrace surface is covered with Fe oxide-enriched nodules. Horizons between 0 and $0.9 \mathrm{~m}$ depth contain up to $25 \%$ nodules. Nodules such as these form at the depth of a seasonally fluctuating water table (Nahon, 1991; Rhoton et al., 1991). The concentration of concretions at the surface and in shallow horizons is evidence that sand-sized and finer material has been removed from the terrace by erosion, leaving the concretions as a lag deposit (Rhoton et al., 1991). Thus, the topographic surface of Terrace 2 is an erosional surface, and substantial material appears to have been removed by erosion.

Terrace 1 is highly dissected (Fig. 3). The remnants retain no bench-like surface morphology, and are recognizable as terraces chiefly by the stratigraphic sequence of sediments overlying the bedrock platform. About 40 to $80 \%$ of the surface of Terrace 1 is covered with nodules. Horizons above $0.77 \mathrm{~m}$ depth contain up to $70 \%$ nodules by weight. This suggests that erosion has removed even more regolith from Terrace 1 than Terrace 2.

\subsection{Terraces 4 and 3}

\section{Soil morphology and chemistry}

Early stages of soil formation, as shown by the Holocene soil at the surface of Terrace 4, result in darkened A horizons, slightly brighter chromas in the subsurface Bw horizons due to Fe oxide coatings on sand grains, and the development of thin ( $\leq 4 \mathrm{~mm}$ ), wavy, discontinuous, reddened lamellae (Pedon CCT-1, Table 2). The textural class of all horizons is fine sand, and is little altered from the parent material. The incipient Holocene lamellae contain slightly more clay, $\mathrm{Fe}_{\mathrm{o}}$, and $\mathrm{Fe}_{\mathrm{d}}$ than the interlamellar matrix (Pedon CCT-1, Tables 2 and 3). The Holocene lamellae appear to be an early stage of lamellae development. Their depth of occurrence appears to be determined by the depth of the wetting front (Moody and Graham, 1994). Profiles consisting of A-Bw-Bt horizons with lamellae commonly occur in young, well-drained sandy soils, having been reported in New York (Dijkerman et al., 1967), western Indiana (Miles and Franzmeier, 1981) and New Zealand (Kemp and McIntosh, 1989).

Most morphological and chemical features reach a greater stage of development in the Terrace 3 soil compared to the Terrace 4 soil (pedons CCT-1 and BNT-6, Tables 2 and 3 ). Three characteristics, representative of these trends, were chosen for graphical display: \% Clay, $\mathrm{Fe}_{\mathrm{d}}$, and $\mathrm{Si}_{\mathrm{T}}$ (Fig. 6a, b). The increases in clay content and $\mathrm{Fe}_{\mathrm{d}}$ with increasing soil age agree with other studies of similar soils (e.g., Miles and Franzmeier, 1981). In addition, total A horizon thickness and lamellae development are greater in the Terrace 3 soil than the Terrace 4 soil (Table 2). Ratios of $\mathrm{Fe}_{\mathrm{o}}: \mathrm{Fe}_{\mathrm{d}}$ are generally lower in the soil developed in the older sediment ( Table 3 ). This trend also agrees with other soil studies (e.g., Alexander, 1974).

\section{Deep regolith morphology and chemistry}

Soils formed in Holocene deposits at the surface of Terrace 4 are immediately underlain by thick, buried deposits of Pleistocene eolianites, which appear to be relicts of soils formed in sand deposits during the Pleistocene (Moody and Graham, 1994). Morphologic and 
Table 3

Selected chemical data for representative pedons, Terraces 4 and 3

\begin{tabular}{|c|c|c|c|c|c|c|c|c|c|c|c|}
\hline \multirow[t]{2}{*}{ Horizon } & \multirow[t]{2}{*}{ Depth (m) } & \multirow[t]{2}{*}{$\mathrm{pH}$} & \multicolumn{4}{|c|}{$\mathrm{g} \mathrm{kg}^{-1}$} & \multicolumn{5}{|c|}{$\mathrm{g} \mathrm{kg}^{-1}$} \\
\hline & & & $\mathrm{Fe}_{\mathrm{p}}$ & $\mathrm{Fe}_{\mathrm{o}}$ & $\mathrm{Fe}_{\mathrm{d}}$ & $\mathrm{Fe}_{\mathrm{o}}: \mathrm{Fe}_{\mathrm{d}}$ & $\mathrm{Al}_{\mathrm{p}}$ & $\mathrm{Al}_{\mathrm{o}}$ & $\mathrm{Al}_{\mathrm{d}}$ & $\mathrm{Si}_{\mathrm{o}}$ & $\mathrm{Si}_{\mathrm{T}}$ \\
\hline \multicolumn{12}{|c|}{ CCT-1, representative pedon, Holocene soil, Terrace 4} \\
\hline A1 & $0-0.12$ & 5.50 & 0.30 & 0.61 & 2.71 & 0.22 & 0.33 & 0.33 & 0.41 & 0.02 & 1.50 \\
\hline A2 & $0.12-0.22$ & 5.85 & 0.45 & 0.68 & 2.54 & 0.27 & 0.33 & 0.33 & 0.43 & 0.02 & 1.43 \\
\hline A3 & $0.22-0.43$ & 5.74 & 0.36 & 0.75 & 2.38 & 0.32 & 0.36 & 0.36 & 0.44 & 0.02 & 1.46 \\
\hline Bw1 & $0.43-1.07$ & 5.52 & 0.51 & 0.83 & 2.55 & 0.32 & 0.34 & 0.38 & 0.65 & 0.08 & 1.28 \\
\hline Bw2 & $1.07-1.29$ & 5.73 & 0.16 & 0.44 & 2.70 & 0.16 & 0.14 & 0.26 & 0.37 & 0.04 & 0.39 \\
\hline \multirow[t]{3}{*}{ Bt1 } & $1.29-2.01$ & & & & & & & & & & \\
\hline & matrix & 5.85 & 0.21 & 0.50 & 2.62 & 0.19 & 0.07 & 0.21 & 0.28 & 0.04 & 1.23 \\
\hline & lamellae & 5.86 & 0.28 & 0.65 & 2.92 & 0.22 & 0.10 & 0.24 & 0.24 & 0.05 & 1.25 \\
\hline
\end{tabular}

BNT-6, representative pedon, Terrace 3

\begin{tabular}{llllllllllll} 
A1 & $0-0.31$ & 5.78 & 0.26 & 0.62 & 4.29 & 0.14 & 0.30 & 0.53 & 0.71 & 0.08 & 0.99 \\
A2 & $0.31-0.60$ & 6.15 & 0.28 & 0.61 & 4.82 & 0.13 & 0.28 & 0.47 & 0.71 & 0.07 & 0.53 \\
A3 & $0.60-0.99$ & 6.18 & 0.25 & 0.63 & 3.94 & 0.16 & 0.17 & 0.36 & 0.72 & 0.05 & 0.65 \\
Bw & $0.99-1.28$ & 6.46 & 0.24 & 0.46 & 4.61 & 0.10 & 0.08 & 0.22 & 0.48 & 0.06 & 1.90 \\
Bt1 & $1.28-1.47$ & 6.14 & 0.16 & 0.51 & 3.23 & 0.16 & 0.10 & 0.26 & 0.46 & 0.05 & 1.91 \\
Bt2 & $1.47-1.76$ & & & & & & & & & & \\
& matrix & 6.88 & 0.10 & 0.45 & 3.25 & 0.14 & 0.06 & 0.18 & 0.40 & 0.05 & 0.05 \\
& lamellae & 6.87 & 0.25 & 1.08 & 7.62 & 0.14 & 0.20 & 0.68 & 1.12 & 0.12 & 7.15 \\
Bt3 & $1.76-1.93$ & & & & & & & & & & \\
& matrix & 6.79 & 0.10 & 0.44 & 4.26 & 0.10 & 0.04 & 0.20 & 0.54 & 0.05 & 0.62 \\
& lamellae & 6.74 & 0.21 & 1.68 & 7.19 & 0.23 & 0.15 & 0.79 & 1.07 & 0.15 & 4.72 \\
Bt4 & $1.93-2.36$ & 6.90 & 0.03 & 0.42 & 3.79 & 0.11 & 0.06 & 0.19 & 0.37 & 0.07 & 1.62 \\
\hline
\end{tabular}

chemical features of these eolianites suggest that they are mostly isolated from present-day pedogenic processes (Moody and Graham, 1994).

The basal sandy regolith of Terrace 4 contains as much clay and $\mathrm{Fe}_{\mathrm{d}}$ as the soil, and more $\mathrm{Si}_{\mathrm{T}}$ than the soil (Table 4, Fig. 6a). The basal unit (POB-6, Table 5) also contains at least as much $\mathrm{Fe}_{\mathrm{p}}$ as the soil. These materials are concentrated into reddened mottles, in a morphologically unaltered matrix. Micromorphologic examination of samples from both sites within the basal regolith showed that most clay and $\mathrm{Fe}$ oxides are illuvial in origin. However, the presence of weathered mafic grains, and ferrans with flecked orientation show that some Fe oxides are authigenic. Ratios of $\mathrm{Fe}_{\mathrm{o}}: \mathrm{Fe}_{\mathrm{d}}$ in the basal unit (Table 5) are variable, but are generally the ratios in the Holocene soil. These data suggest that the basal unit is as intensely weathered as the soil, and that the basal unit is receiving clay, organo-metallic complexes, and $\mathrm{Fe}$ oxides by illuviation, and opaline silica by precipitation from fluids percolating through the basal sediments. Pedogenic-type processes seem to be as active in the basal regolith as in the soil.

The basal unit above the shoreline angle of Terrace 4 has a very high content of crystalline Fe oxides in the yellowish brown matrix, and low ratios of $\mathrm{Fe}_{\mathrm{o}}: \mathrm{Fe}_{\mathrm{d}}$ (HCT-1, Table 4). The $\mathrm{pH}$ of HCT-1 material is much lower than elsewhere in Terrace 4 sediments, presumably due to more intense weathering of aluminosilicates. This unit of the regolith in Terrace 4 is morphologically more developed and chemically more altered than the soil and seaward 

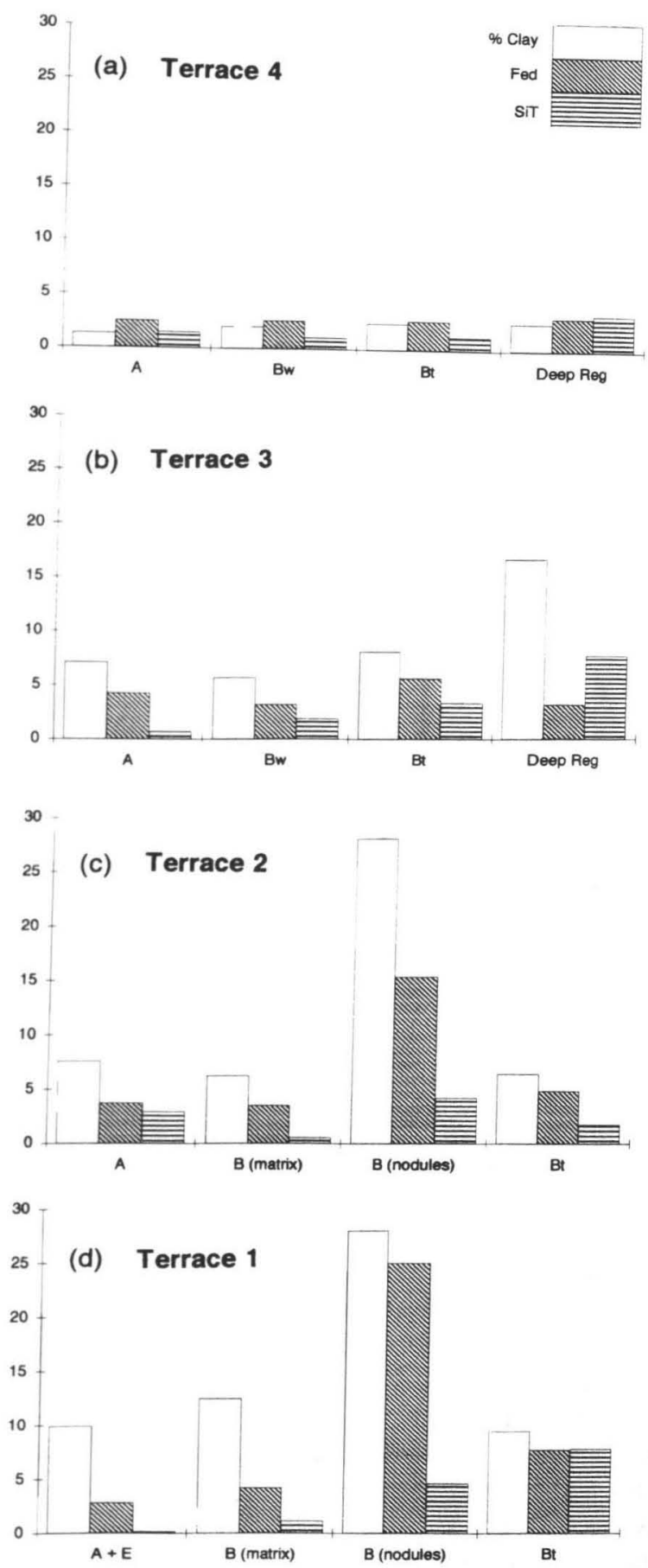

Fig. 6. Comparison of \% Clay, dithionite-extractable $\mathrm{Fe}\left(\mathrm{Fe}_{\mathrm{d}}\right)$ and Tiron-extractable $\mathrm{Si}\left(\mathrm{Si}_{\mathrm{T}}\right)$ of soils and deep regolith of (a) Terrace 4, (b) Terrace 3, and soils of (c) Terrace 2 and (d) Terrace 1. Values were calculated as weighted averages for each horizon shown. Vertical scale for each morphological and chemical feature is the same on all graphs. Units of $\mathrm{Fe}_{\mathrm{d}}$ and $\mathrm{Si}_{\mathrm{T}}$ are $\mathrm{g} \mathrm{kg}^{-1}$. 
Table 4

Selected morphological features of representative stratigraphic sections, basal regolith units, Terraces 4 and 3

Depth Moist color $\%(\mathrm{w} / \mathrm{w}) \quad$ FC:TC Structure Clay films Mottles Mottles

$(\mathrm{m})$

Sand Silt Clay

Color

\% Clay FC:TC

POB-6, late Pleistocene basal unit, Terrace 4

Overburden at 0 to $43 \mathrm{~m}$ depth

\begin{tabular}{|c|c|c|c|c|c|c|c|c|c|c|c|}
\hline $43.0-46.0^{\mathrm{a}}$ & $10 \mathrm{YR} 4 / 4$ & nd & nd & nd & nd & $\mathrm{m}$ & co \& br & 0 & - & - & - \\
\hline $46.0-47.2$ & $10 Y R 4 / 4$ & 97.9 & 0.6 & 1.5 & 0.8 & $\mathrm{~m}$ & co \& br & $\mathrm{m} 3 \mathrm{~d}$ & 10YR 3/4 & 4.3 & 0.6 \\
\hline $47.2-48.3$ & $10 \mathrm{YR} 4 / 4$ & 97.2 & 1.1 & 1.8 & 0.9 & $\mathrm{~m}$ & co \& br & $\mathrm{c} 2 \mathrm{~d}$ & 7.5 YR $3 / 4$ & 4.8 & 0.6 \\
\hline $48.3-48.8$ & $2.5 Y 4 / 4$ & 98.2 & 0.1 & 1.7 & 0.8 & $\mathrm{~m}$ & co \& br & $\mathrm{m} 3 \mathrm{p}$ & 7.5 YR $3 / 4$ & 4.4 & 0.8 \\
\hline $48.8-49.8$ & $2.5 Y 4 / 4$ & 96.7 & 2.2 & 1.1 & 0 & $\mathrm{~m}$ & 0 & 0 & - & - & - \\
\hline $\begin{array}{l}49.8-51.3 \\
\text { (littoral gra }\end{array}$ & 10 YR $6 / 2$ & nd & nd & nd & nd & $\mathrm{m}$ & co & 0 & - & - & - \\
\hline $\begin{array}{l}51.3-52.8 \\
\text { (bedrock te }\end{array}$ & $\begin{array}{l}10 \mathrm{YR} 7 / 2 \\
\text { e platform) }\end{array}$ & - & - & - & - & - & - & 0 & - & - & - \\
\hline
\end{tabular}

HCT-1, late Pleistocene basal unit, above the shoreline angle, Terrace 4 Overburden at 0 to $6.9 \mathrm{~m}$ depth

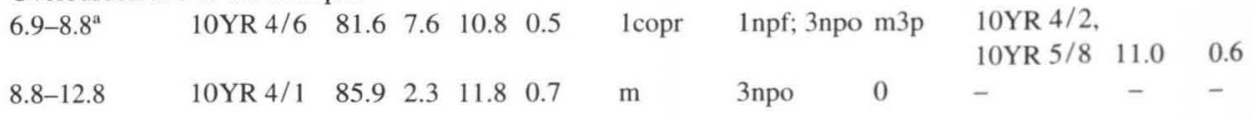

NSC-3 basal unit, Terrace 3

Overburden at 0 to $7 \mathrm{~m}$ depth

\begin{tabular}{|c|c|c|c|c|c|c|c|c|c|c|c|}
\hline $7.0-7.6^{\mathrm{a}}$ & $10 \mathrm{YR} 4 / 4$ & 88.2 & 7.2 & 4.6 & 0.4 & $\mathrm{~m}$ & co \& br & 0 & - & - & - \\
\hline \multirow[t]{2}{*}{$7.6-8.0$} & $10 Y R 4 / 4$ & 86.9 & 4.8 & 8.3 & 0.4 & $\mathrm{~m}$ & co \& br & $\mathrm{m} 3 \mathrm{~d}$ & 10 YR $5 / 6$, & & \\
\hline & $2.5 Y 3 / 2$ & nd & nd & & & & & & & & \\
\hline \multirow[t]{2}{*}{$8.0-8.6$} & $2.5 Y 3 / 2$ & 81.0 & 4.2 & 14.8 & 0.6 & $1 \mathrm{cpr}$ & 2npo & $\mathrm{m} 3 \mathrm{~d}$ & 10YR 5/6, & & \\
\hline & $2.5 Y 3 / 2$ & 22.8 & 0.6 & & & & & & & & \\
\hline \multirow[t]{2}{*}{$8.6-9.3$} & 10 YR $3 / 6$ & 84.7 & 3.0 & 12.3 & 0.6 & $\mathrm{~m}$ & Inpo & $\mathrm{m} 3 \mathrm{p}$ & $2.5 Y 5 / 0$ & & \\
\hline & 7.5 YR $4 / 6$ & 21.6 & 0.6 & & & & & & & & \\
\hline $9.3-10.3$ & 10YR $3 / 6$ & 83.8 & 2.8 & 13.4 & 0.5 & $\mathrm{~m}$ & 2 npo & $\mathrm{m} 3 \mathrm{~d}$ & $10 \mathrm{YR} 4 / 3$ & nd & nd \\
\hline
\end{tabular}

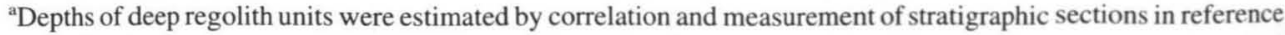
to the depth of occurrence below the representative pedon for each terrace.

basal unit of Terrace 4, and is even more chemically altered than the soils on Terrace 3 . Two factors may influence this condition. First, sediment may have been eroded from the older terrace toe, and deposited at the shoreline angle during coastal erosion, as can be observed occurring at the modern sea cliff. Perhaps more importantly, the stratigraphic position of this unit makes it the recipient of groundwater flowing along the bedrock of the former sea cliff and the shoreline angle (shown in Fig. 4, and described more completely by Moody and Graham, 1994). By the latter interpretation, the regolith at this position is more weathered due to increased wetness, and is subject to more illuviation of fines from overlying sediments and from older terrace sediments.

Micromorphologic examination of regolith samples from the seaward edge of the basal unit showed that simple packing voids between sand grains are partially filled with clay sized material. Above the shoreline angle, more of this pore space is filled, due to intense 
Table 5

Selected chemical data for representative stratigraphic sections, deep regolith, Terraces 4 and 3

\begin{tabular}{|c|c|c|c|c|c|c|c|c|c|c|}
\hline \multirow[t]{2}{*}{ Depth (m) } & \multirow[t]{2}{*}{$\mathrm{pH}$} & \multicolumn{4}{|c|}{$\mathrm{g} \mathrm{kg}^{-1}$} & \multicolumn{5}{|c|}{$\mathrm{g} \mathrm{kg}^{-1}$} \\
\hline & & $\mathrm{Fe}_{\mathrm{p}}$ & $\mathrm{Fe}_{\mathrm{o}}$ & $\mathrm{Fe}_{\mathrm{d}}$ & $\mathrm{Fe}_{\mathrm{o}}: \mathrm{Fe}_{\mathrm{d}}$ & $\mathrm{Al}_{\mathrm{p}}$ & $\mathrm{Al}_{\mathrm{o}}$ & $\mathrm{Al}_{\mathrm{d}}$ & $\mathrm{Si}_{\mathrm{o}}$ & $\mathrm{Si}_{\mathrm{T}}$ \\
\hline \multicolumn{11}{|c|}{$\begin{array}{l}\text { POB-6, basal regolith, distal position, Terrace } 4 \\
46.0-47.2\end{array}$} \\
\hline matrix & 7.36 & 0.17 & 0.70 & 1.40 & $\stackrel{\circ}{0.50}$ & 0.06 & 0.14 & 0.18 & 0.04 & 1.14 \\
\hline $\begin{array}{l}\text { mottles } \\
47.2-48.3\end{array}$ & 7.54 & 0.21 & 1.03 & 3.80 & 0.27 & 0.17 & 0.27 & 2.66 & 0.14 & 6.38 \\
\hline matrix & 7.75 & 0.07 & 0.59 & 3.14 & 0.19 & 0.06 & 0.16 & 2.18 & 0.08 & 1.95 \\
\hline $\begin{array}{l}\text { mottles } \\
48.3-48.8\end{array}$ & 7.28 & 0.72 & 1.46 & 4.74 & 0.31 & 0.29 & 0.41 & 2.68 & 0.66 & 5.78 \\
\hline matrix & 7.64 & 0.15 & 0.83 & 1.19 & 0.70 & 0.04 & 0.14 & 0.14 & 0.10 & 1.21 \\
\hline mottles & 7.31 & 0.76 & 1.07 & 8.27 & 0.13 & 0.09 & 0.34 & 3.70 & 0.42 & 6.54 \\
\hline $48.8-49.8$ & 7.75 & 0.25 & 0.75 & 2.01 & 0.37 & 0 & 0.13 & 0.14 & 0.07 & 2.12 \\
\hline
\end{tabular}

HCT-1, basal regolith, above the shoreline angle, Terrace 4 $6.9-8.8$

matrix

mottles

$5.47 \quad 0.13$

1.17

13.07

0.09

$0.01 \quad 0.22$

0.37

0.11

2.37

0.04

0.27

$0.27 \quad 0.06$

10.42

NSC-3, basal regolith, distal position, Terrace 3

$\begin{array}{lllllllllll}7.0-7.6 & 7.11 & 0.13 & 0.27 & 1.80 & 0.15 & 0 & 0.08 & 0.15 & 0.03 & 2.93 \\ 7.6-8.0 & 6.94 & 0.08 & 0.21 & 1.37 & 0.15 & 0 & 0.08 & 0.16 & 0.03 & 7.75 \\ 8.0-8.6 & 5.92 & 0.10 & 0.32 & 1.98 & 0.16 & 0.02 & 0.33 & 0.33 & 0.06 & 8.12 \\ 8.6-9.3 & & & & & & & & & & \\ \text { matrix } & 6.16 & 0.09 & 1.36 & 7.72 & 0.18 & 0.11 & 0.37 & 0.54 & 0.18 & 6.95 \\ \text { mottles } & 6.10 & 0.10 & 0.35 & 1.45 & 0.04 & 0.35 & 0.35 & 0.09 & 7.79 & \\ 9.3-10.3 & & & & & & & & & & \\ \text { matrix } & 6.33 & 0.09 & 0.92 & 5.79 & 0.16 & 0.02 & 0.29 & 0.55 & 0.19 & 8.17 \\ \text { mottles } & 6.26 & 0.08 & 0.33 & 1.77 & 0.05 & 0.30 & 0.33 & 0.09 & 7.75 & \end{array}$

NSC-3A, basal regolith, above shoreline angle, Terrace 3

(Overburden at 0 to $4 \mathrm{~m}$ )

\begin{tabular}{lllllllllll}
$4.0-5.0$ & & & & & & & & & & \\
matrix & 6.40 & 0.12 & 1.25 & 16.06 & 0.08 & 0.06 & 0.39 & 0.83 & 0.35 & 7.66 \\
mottles & 6.36 & 0.08 & 0.25 & 1.63 & 0.15 & 0.02 & 0.42 & 0.42 & 0.26 & 10.53 \\
\hline
\end{tabular}

weathering and illuviation, as suggested above. As simple packing voids progressively fill with clay-sized material, water flowing through the matrix must seek cracks and channels as paths of preferential flow. During the rainy season, sand contiguous with cracks and channels becomes saturated with water. Iron adjacent to these saturated zones is reduced by microbial activity and solubilized. The Fe in solution can diffuse into ped interiors which contain entrained oxygen in small pores, and reprecipitate, or can be carried away in solution in groundwater. In this way, the basal unit develops redoximorphic features consisting of gray, Fe-depleted mottles around cracks and channels, within an Fe-rich matrix (Vepraskas, 1992). Pedogenesis within the basal regolith probably began immediately following emer- 
Table 6

Selected morphological features of representative pedons, Terraces 2 and 1

\begin{tabular}{|c|c|c|c|c|c|c|c|}
\hline \multirow{2}{*}{ Horizon } & \multirow{2}{*}{$\begin{array}{l}\text { Depth } \\
\text { (m) }\end{array}$} & \multirow{2}{*}{$\begin{array}{l}\text { Moist } \\
\text { color }\end{array}$} & $\%(w / w)$ & \multirow{2}{*}{ Structure Clay films } & \multirow[t]{2}{*}{ Mottles } & \multicolumn{2}{|c|}{ Mottles } \\
\hline & & & Sand Silt Clay FC:TC & & & Color & $\%$ Clay FC:TC \\
\hline
\end{tabular}

BNT-5, representative pedon, Terrace 2 (coarse-loamy, mixed, thermic Typic Epiaquoll)

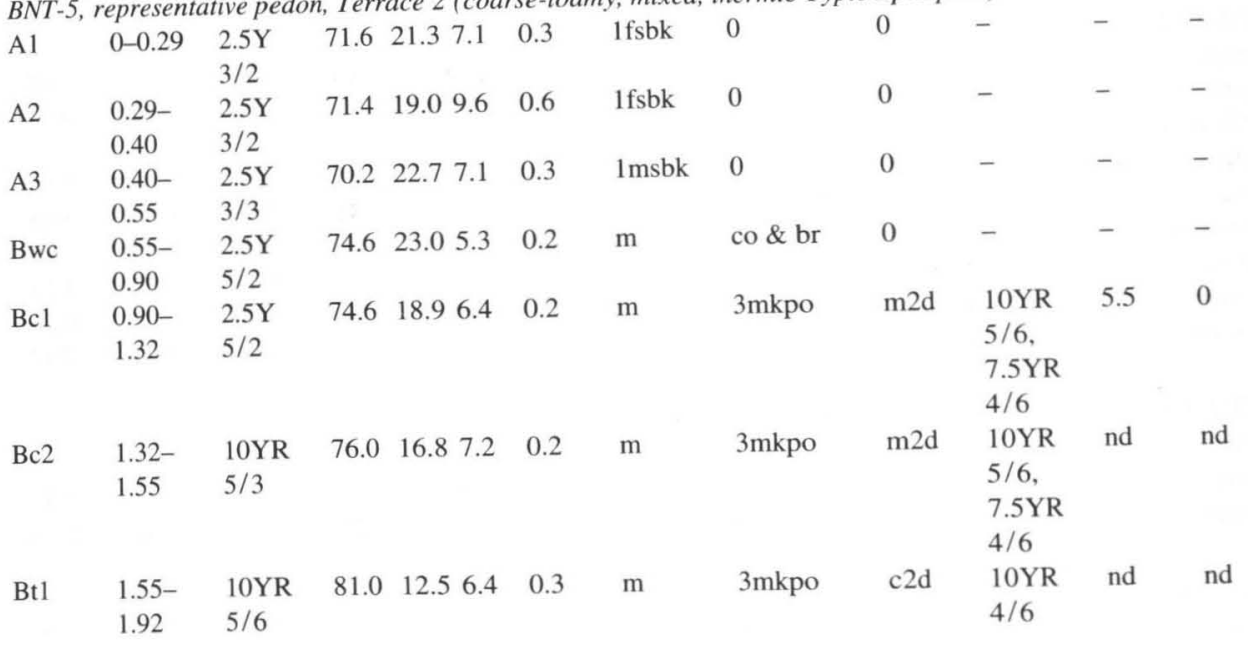

SHC-1, representative pedon, Terrace 1 (coarse-loamy, mixed, thermic Aeric Epiaqualf)

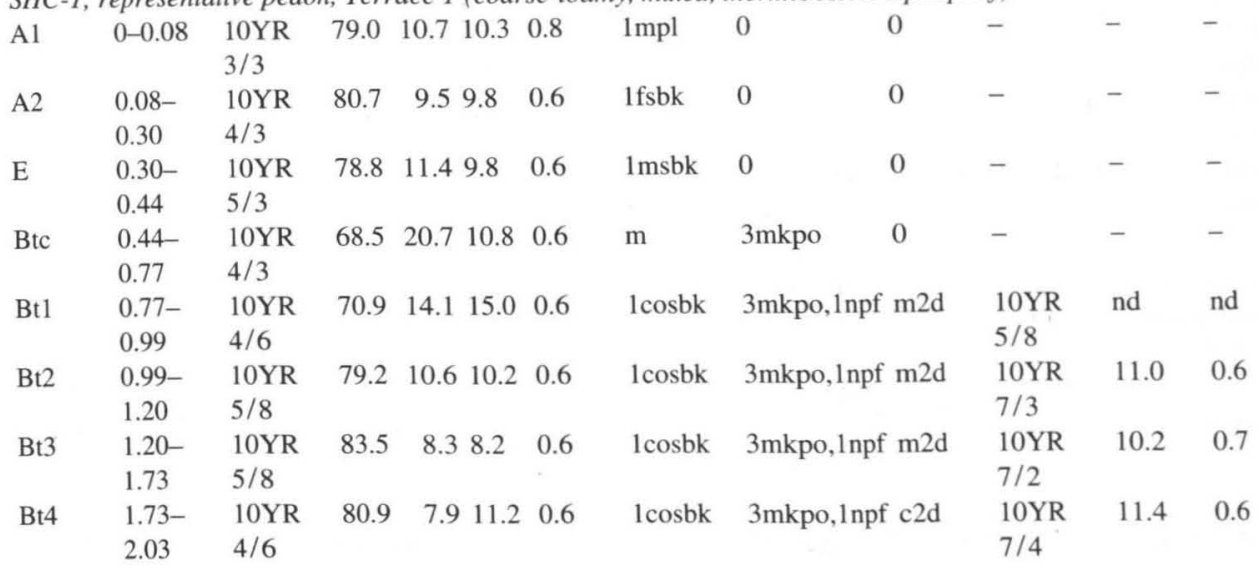

gence of Terrace 4. Data used to assemble Fig. 5 and Table 1 suggest these features may have began forming between 120 and $48 \mathrm{ka}$.

Overall, the deep regolith of Terrace 3 contains substantially more clay and $\mathrm{Si}_{\mathrm{T}}$, and slightly more $\mathrm{Fe}_{\mathrm{d}}$, than the corresponding basal unit of Terrace 4 (Fig. 6b). The basal unit of Terrace 3 has more developed redoximorphic features, even at the seaward edge, than Terrace 4 deep regolith: gray mottles are as much as $6 \mathrm{~cm}$ in diameter (compared to $1 \mathrm{~cm}$ in stratigraphic section HCT-1), and the mottles are more prominent. The matrix of the 
Table 7

Selected chemical data for representative pedons, Terraces 2 and 1

\begin{tabular}{|c|c|c|c|c|c|c|c|c|c|c|c|}
\hline \multirow[t]{2}{*}{ Horizon } & \multirow{2}{*}{$\begin{array}{l}\text { Depth } \\
\text { (m) }\end{array}$} & \multirow{2}{*}{$\mathrm{pH}$} & \multicolumn{4}{|c|}{$\mathrm{g} \mathrm{kg}^{-1}$} & \multicolumn{5}{|c|}{$\mathrm{g} \mathrm{kg}^{-1}$} \\
\hline & & & $\mathrm{Fe}_{\mathrm{p}}$ & $\mathrm{Fe}_{\mathrm{o}}$ & $\mathrm{Fe}_{\mathrm{d}}$ & $\mathrm{Fe}_{\mathrm{o}}: \mathrm{Fe}_{\mathrm{d}}$ & $\mathrm{Al}_{\mathrm{p}}$ & $\mathrm{Al}_{\mathrm{o}}$ & $\mathrm{Al}_{\mathrm{d}}$ & $\mathrm{Si}_{\mathrm{o}}$ & $\mathrm{Si}_{\mathrm{T}}$ \\
\hline \multicolumn{12}{|c|}{$B N T-5$, representative pedon, Terrace 2} \\
\hline A1 & $0-0.29$ & 5.62 & 0.55 & 0.55 & 4.00 & 0.14 & 0.80 & 0.76 & 0.97 & 0.22 & 4.09 \\
\hline A2 & $0.29-0.40$ & 5.91 & 0.41 & 0.45 & 3.81 & 0.12 & 0.45 & 0.54 & 0.92 & 0.14 & 3.27 \\
\hline A3 & $0.40-0.55$ & 6.11 & 0.37 & 0.45 & 3.11 & 0.14 & 0.53 & 0.39 & 0.75 & 0.11 & 0.28 \\
\hline Bwc & $0.55-0.90$ & 6.44 & 0.24 & 0.26 & 1.91 & 0.14 & 0.08 & 0.22 & 0.50 & 0.12 & 0.12 \\
\hline \multirow[t]{3}{*}{$\mathrm{Bcl}$} & $0.90-1.32$ & & & & & & & & & & \\
\hline & matrix & 6.71 & 0.22 & 0.47 & 3.23 & 0.14 & 0.33 & 0.58 & 0.82 & 0.09 & 0.45 \\
\hline & nodules & nd & 0.42 & 3.15 & 15.33 & 0.20 & 1.39 & 3.92 & 5.30 & 2.35 & 4.18 \\
\hline $\mathrm{Bc} 2$ & $1.32-1.55$ & 6.29 & 0.22 & 0.41 & 6.22 & 0.06 & 0.19 & 0.49 & 1.46 & 0.18 & 1.24 \\
\hline Btl & $1.55-1.92$ & 6.39 & 0.06 & 0.14 & 4.83 & 0.03 & 0.05 & 0.19 & 0.82 & 0.21 & 1.72 \\
\hline Bt2 & $1.92-2.71$ & 6.35 & 0.03 & 0.13 & 5.47 & 0.02 & 0.05 & 0.18 & 1.03 & 0.24 & 1.14 \\
\hline
\end{tabular}

SHC-1, representative pedon, Terrace 1

\begin{tabular}{|c|c|c|c|c|c|c|c|c|c|c|c|}
\hline Al & $0-0.08$ & & & & & & & & & & \\
\hline & matrix & 5.05 & 0.21 & 0.36 & 2.47 & 0.14 & 0.33 & 0.39 & 0.67 & 0.06 & 0.38 \\
\hline & nodules & nd & 0.43 & 3.91 & 24.12 & 0.16 & 0.88 & 4.91 & 7.35 & 4.10 & 5.39 \\
\hline A2 & $0.08-0.30$ & & & & & & & & & & \\
\hline & matrix & 5.39 & 0.26 & 0.41 & 2.95 & 0.14 & 0.20 & 0.34 & 0.75 & 0.06 & 0.06 \\
\hline & nodules & nd & 1.25 & 3.46 & 25.03 & 0.14 & 1.00 & 5.38 & 6.17 & 2.64 & 2.96 \\
\hline E & $0.30-0.44$ & & & & & & & & & & \\
\hline & matrix & 5.43 & 0.09 & 0.19 & 3.02 & 0.06 & 0.10 & 0.21 & 0.69 & 0.06 & 0.37 \\
\hline & nodules & nd & 0.91 & 4.79 & 22.02 & 0.21 & 1.23 & 5.82 & 5.97 & 2.29 & 4.59 \\
\hline Btc & $0.44-0.77$ & & & & & & & & & & \\
\hline & matrix & 5.47 & 0.10 & 0.22 & 3.55 & 0.06 & 0.12 & 0.32 & 0.99 & 0.06 & 0.42 \\
\hline & nodules & nd & 0.73 & 2.01 & 24.08 & 0.08 & 0.80 & 2.40 & 4.21 & 0.96 & 5.11 \\
\hline Bt1 & $0.77-0.99$ & & & & & & & & & & \\
\hline & matrix & 5.76 & 0.07 & 0.21 & 5.20 & 0.04 & 0.15 & 0.28 & 1.28 & 0.06 & 2.16 \\
\hline & nodules & nd & 0.45 & 2.03 & 26.84 & 0.08 & 0.35 & 1.04 & 4.76 & 0.34 & 5.81 \\
\hline Bt2 & $0.99-1.20$ & & & & & & & & & & \\
\hline & matrix & 5.91 & 0.06 & 0.34 & 8.17 & 0.03 & 0.19 & 0.53 & 1.72 & 0.12 & 9.58 \\
\hline & mottles & nd & 0.05 & 0.28 & 8.12 & 0.03 & 0.11 & 0.46 & 1.70 & 0.10 & 4.25 \\
\hline $\mathrm{Bt} 3$ & $1.20-1.72$ & & & & & & & & & & \\
\hline & matrix & 5.31 & 0.04 & 0.21 & 8.98 & 0.02 & 0.09 & 0.51 & 1.46 & 0.13 & 11.41 \\
\hline & mottles & nd & 0.02 & 0.29 & 7.41 & 0.04 & 0.13 & 0.37 & 1.87 & 0.06 & 7.13 \\
\hline & $1.72-2.03$ & & & & & & & & & & \\
\hline & matrix & 5.91 & 0.03 & 0.25 & 7.04 & 0.04 & 0.11 & 0.49 & 1.34 & 0.15 & 6.35 \\
\hline & mottles & nd & 0.02 & 0.18 & 5.64 & 0.03 & 0.15 & 0.45 & 1.24 & 0.08 & 5.40 \\
\hline
\end{tabular}

Terrace 3 deep regolith contains more clay and silt than the basal unit of Terrace 4. Gray mottles are contiguous with fractures and contain more clay than the yellowish brown matrix, due to medium thick clay films lining many of the fractures (NSC-3, Table 4). Microscopic examination of thin sections from the matrix showed ferriargillans with strong continuous orientation, nearly filling packing voids and channels. Some yellowish brown ferrans have flecked orientation, and these Fe oxides are probably authigenic. Gray argillans 
in the Fe-depleted mottles have strong, continuous orientation, and nearly fill simple packing voids, planar voids, and channels.

Sand deposits from above the shoreline angle position of Terrace 3 (samples NSC-3A, Table 5) show chemical trends similar to those exhibited by the equivalent stratigraphic position of Terrace 4: the brown matrix contains more $\mathrm{Fe}_{\mathrm{d}}$ and $\mathrm{Al}_{\mathrm{d}}$ than the basal unit at the seaward edge.

\subsection{Terraces 2 and 1}

Soil morphology and chemistry

As discussed earlier, the Terrace 2 soil contains numerous Fe oxide nodules above about $1.5 \mathrm{~m}$ depth (Pedon BNT-5, Table 6). The soil contains less to slightly more clay, $\mathrm{Fe}_{\mathrm{d}}$, and $\mathrm{Si}_{\mathrm{T}}$ (excepting nodules) than the Terrace 3 soil and deep regolith (Fig. $6 \mathrm{c}$ ).

(a)

Terrace 4

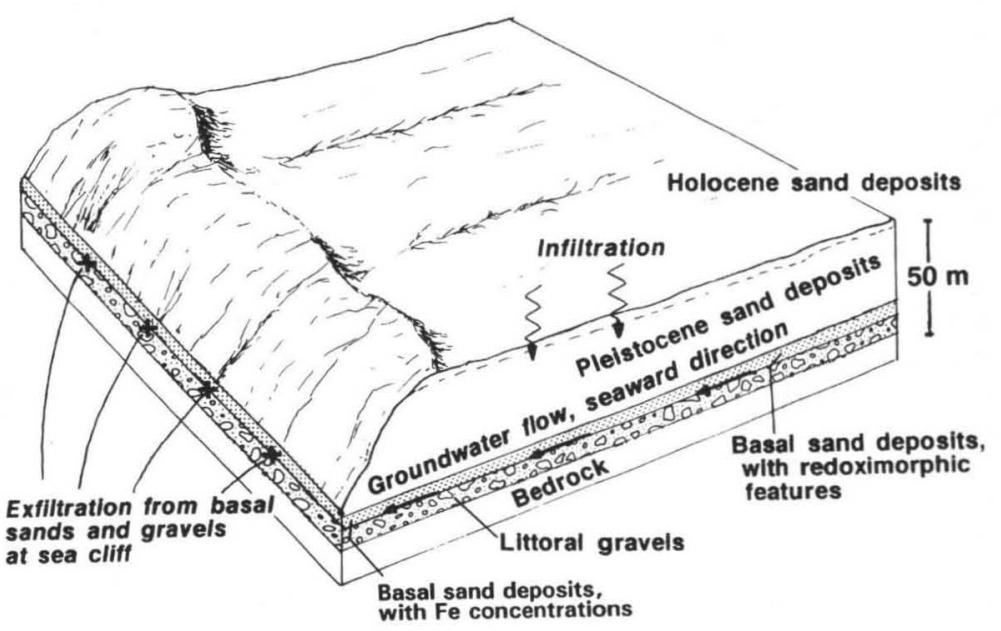

(b)

Terrace 3

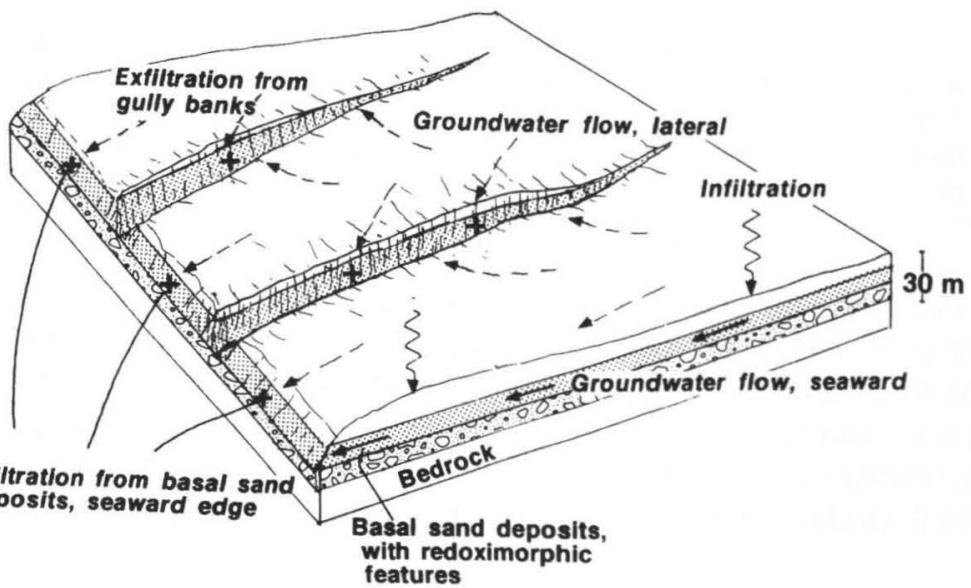




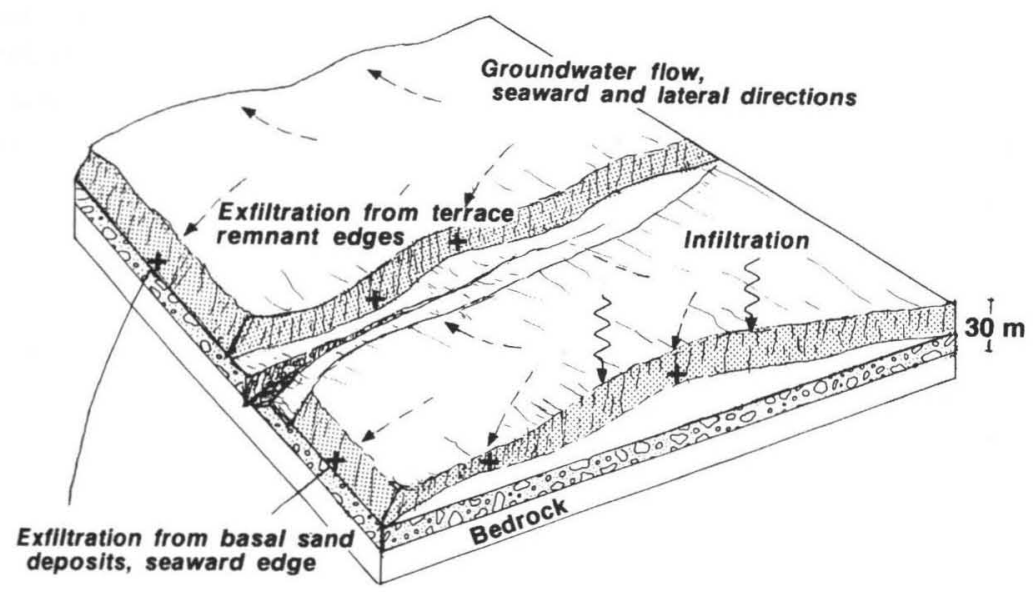

(d)

\section{Terrace 1}

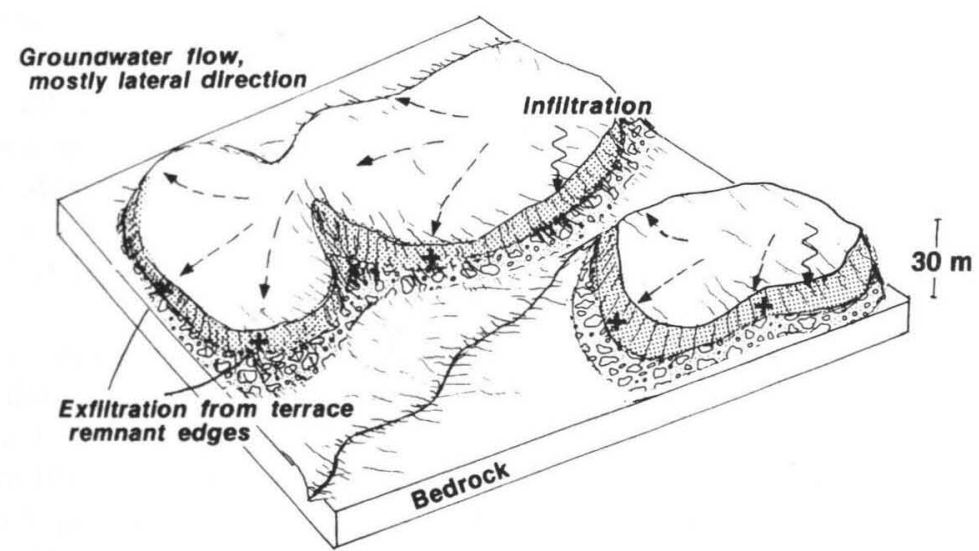

Fig. 7. Block diagrams of (a) Terrace 4, (b) Terrace 3, (c) Terrace 2 and (d) Terrace 1, showing interpretation of the relationships of landscape evolution, groundwater movement and pedogenesis. Exfiltration sites on each terrace are shown by plusses.

The Terrace 1 soil (pedon SHC-1, Table 6) has a thinner A horizon than the Terrace 2 soil, and a weakly developed E horizon, which the Terrace 2 soil lacks. The soil contains Fe oxide nodules to about $0.8 \mathrm{~m}$ depth. Compared to the Terrace 2 soil, the matrix of the upper profile in the Terrace 1 soil (Fig. 6d) contains substantially more clay, less (A+E horizons) to slightly more ( $\mathrm{B}$ horizons) $\mathrm{Fe}_{\mathrm{d}}$, and substantially less ( $\mathrm{A}+\mathrm{E}$ horizons) to slightly more ( $\mathrm{B}$ horizons) $\mathrm{Si}_{\mathrm{T}}$. Deep horizons, below the nodules, contain substantially more clay, $\mathrm{Fe}_{\mathrm{d}}$, and $\mathrm{Si}_{\mathrm{T}}$ than corresponding horizons in the Terrace 2 soil (Fig. 6d).

Nodules in both the Terrace 2 and Terrace 1 soils contain much more clay (about 28\%, estimated from point counts of thin sections and converted to weight percent), more $\mathrm{Fe}_{\mathrm{d}}$, 
and more $\mathrm{Si}_{\mathrm{T}}$, than the soil matrix (Table 7 and Fig. $6 \mathrm{c}, \mathrm{d}$ ). The nodules are relict features, having formed in response to a fluctuating water table (Nahon, 1991; Rhoton et al., 1991). It appears that the process of nodule formation has concentrated $\mathrm{Fe}$ oxides, allophanic material, and opaline silica into the sandy matrix of these roughly spherical bodies. After this segregation occurred, and upon exposure of the nodular horizons to near surface processes, noncemented clay and products of subsequent weathering were removed from the matrix of the upper horizons by eluviation. The progressive loss of $\mathrm{Fe}, \mathrm{Al}$, and $\mathrm{Si}$ from the upper horizons, even resulting in a weakly developed E horizon in the Terrace 1 soil, represents an advanced stage of weathering in soils in this terrace sequence.

Iron-depleted mottles and concentrations of Fe oxides and other substances deep in the soils of Terraces 2 and 1 resemble the basal sandy regolith more than the soils of the younger two terraces. Progressive erosion of soils and regolith from the surfaces of terrace deposits has resulted in soil morphological features - A horizons and, in the Terrace 1 soil, an E horizon - superimposed over what was once deep regolith.

\section{Interpretation of processes}

This sequence of sand deposits on marine terraces has allowed us to examine changes in pedogenic processes related to stratigraphy, landscape development, and groundwater movement. Eolian deposition of new material and redistribution of the surface sand deposits by wind and water occur at terrace surfaces. Early in terrace history, erosion and redeposition result in a complex topographic surface (Fig. 7a). Water movement at the surface is downward in the well-drained soils which develop at the surface of thick, permeable sand deposits. Soils which develop in young sand deposits have darkened A horizons, brighter or slightly redder $\mathrm{Bw}$ horizons, and weathering products concentrated in lamellae via downward illuviation. Lamellae are slightly more cohesive than the interlamellar matrix, but the soils and regolith are easily eroded by wind and water.

At depth, water movement depends on the stratigraphic sequence of deposits overlying the terrace platform. A seasonal, perched water table develops in the regolith above the bedrock platform. Groundwater is transmitted through packing voids between sand grains, and between coarser particles in the basal gravels, and the flow moves generally in a seaward direction due to the gentle seaward slope of the terrace platform (Fig. 7a). Colloids and solutes carried in groundwater are deposited in packing voids, gradually filling them. As packing voids are filled, water must seek cracks and channels to serve as preferential flow paths. In this way, pedogenic features begin to affect the paths of water movement. Under saturated conditions and in the presence of organic matter and microorganisms, redoximorphic features develop, consisting of gray mottles around cracks and channels, in a yellowish brown matrix. In the Terrace 4 regolith, redoximorphic features have formed only above the shoreline angle.

Erosion by wind and runoff causes planation of the Terrace 3 (Fig. 7b) topographic surface between streams and gullies, completely subduing dune morphology. With increased time of soil development, compared to Terrace 4, lamellae have become thicker, more clayey, and redder. Stream incision has changed internal drainage patterns, causing groundwater to flow not only seaward, but also toward stream banks (Fig. 7b). Groundwater 
continues to carry solutes and suspended colloids, some of which are deposited in pore space. Redoximorphic features continue to develop in deep regolith, and argillans form in cracks and channels within gray mottles, as clays are deposited on the edges of these flow paths.

On Terrace 2 (Fig. 7c), with a greater degree of erosion and soil and regolith development, Fe oxide enriched nodules have developed at the depth of the fluctuating water table, through a process of chemical self organization. Stream incision has deepened and the level of the seasonal water table has dropped. Removal of soft and friable regolith material from the surface, through wind erosion and runoff has resulted in a gradual lowering of the topographic surface and a surficial lag deposit of concretions. At depth, groundwater flow toward terrace edges continues (Fig. 7c), and redoximorphic features continue to develop.

On Terrace 1, sand deposits have been highly eroded, and marine terrace landform morphology is largely obliterated (Fig. 7d). As the altered deep regolith is exposed by erosion of the overburden, soil forming processes have begun to imprint new morphologic features over the relict deep regolith morphology. The A horizon is thinner than in the Terrace 2 soil, and an E horizon has developed. Redoximorphic features continue to develop, and are very prominent in the sandy soil above the littoral gravels and bedrock platform.

Each soil/deep regolith profile in this sequence of marine terraces represents a "snapshot" in a continuum of changing pedogenic-geomorphic-hydrologic conditions. The interrelationship of terrace stratigraphy, geomorphology, hydrology, and pedology can be visualized as a series of feedback mechanisms. Early in terrace history, terrace morphology and stratigraphy control the path and direction of subsurface water movement. In turn, water movement through terrace sediments determines the emplacement of clays and Fe oxides. Later, plugging of packing voids forces water to seek macropores as flow paths, and redoximorphic features develop. Stream incision changes the direction of subsurface water movement, which further affects pedogenesis. The use of morphological and chemical features to interpret pedogenic processes related to hydrology is an adjunct to studies of chronosequences of soils on marine terraces. Study of the geomorphic and pedogenic evolution of marine terraces helps understanding of water, solute, and contaminant movement through sandy regolith, and erosion processes in coastal environments.

\section{Acknowledgements}

The authors wish to thank Tom Rice for suggesting the study area; Paul Mosher, Peggy Hart, and Jim Moody for field assistance; Peter Sadler, Oliver Chadwick, Tom Rice, and April Ulery for helpful discussions; and Jim Moody for drafting. We are grateful to John Southon, Lawrence Livermore National Laboratory, for providing radiocarbon dates. This paper benefitted from reviews by R.B. Daniels and Tom Rice.

\section{References}

Alexander, E.B., 1974. Extractable iron in relation to soil age on terraces along the Truckee River, Nevada. Soil Sci. Soc. Am. Proc., 38: 121-124. 
Aniku, J.R.F. and Singer, M.J., 1990. Pedogenic iron oxide trends in a marine terrace chronosequence. Soil Sci. Soc. Am. J., 54: 147-152.

Bascomb, C.L., 1968. Distribution of pyrophosphate-extractable iron and organic carbon in soils of various groups. J. Soil Sci., 19: 251-268.

Bates, R.L. and Jackson, J.A., 1984. Dictionary of Geological Terms. 3rd ed. Anchor Press, Doubleday, NY.

Birkeland, P.W., 1972. Late Quaternary eustatic sea-level changes along the Malibu coast, Los Angeles County, California. J. Geol., 80: 432-448.

Bishop, D.G., 1991. High-level marine terraces in western and southern New Zealand: indicators of the tectonic tempo of an active continental margin. In: D.I.M. Macdonald (Editor), Sedimentation, Tectonics and Eustasy: Sea Level Changes at Active Margins. Int. Assoc. Sedimentol. Spec. Publ., 12: 69-78.

Blatt, H., Middleton, G. and Murray, R., 1980. Origin of sedimentary rocks. 2nd ed. Prentice-Hall, Englewood Cliffs, NJ.

Bockheim, J.G., Kelsey, H.M. and Marshall, J.G., III, 1992. Soil development, relative dating, and correlation of late Quaternary marine terraces in southwestern Oregon. Quat. Res., 37: 60-74.

Bradley, W.C. and C.B. Griggs, 1976. Form, genesis and deformation of central California wave-cut platforms. Geol. Soc. Am. Bull., 87: 433-449.

Brewer, R., 1976. Fabric and Mineral Analysis of Soils. 2nd ed. Robert E. Krieger Publishing Co., Huntington, NY.

Cleveland, G.B., 1978. Geologic map of the Point Buchon area, San Luis Obispo County, California. Calif. Div. Mines and Geology, Open File Report 78-17.

Cooper, W.S., 1967. Coastal dunes of California. Geol. Soc. Am. Mem., 104.

Dijkerman, J.C., Cline, M.G. and Olson, G.W., 1967. Properties and genesis of textural subsoil lamellae. Soil Sci., 104: 7-16.

Emery, K.O. and Aubrey, D.G., 1991. Sea Levels, Land Levels and Tide Gauges. Springer, New York.

Ernstrom, D.J., 1984. Soil survey of San Luis Obispo County, California, coastal part. U.S. Dept. of Agriculture, Soil Conservation Service. U.S. Gov. Print. Office, Washington, DC.

Gee, G.W. and Bauder, J.W., 1986. Particle size analysis. In: A. Klute (Editor), Methods of soil analysis. Part 1. 2nd ed. Agron. Monogr. 9. ASA, Madison, WI, pp. 383-411.

Hall, C.A., Jr., Ernst, W.G., Prior, S.W. and Wiese, J.W., 1979. Geologic map of the San Luis Obispo - San Simeon region, California. U.S. Geol. Surv. Misc. Inv. Series I-1097.

Hallam, A., 1992. Phanerozoic Sea-Level Changes. Columbia Univ. Press, New York.

Jackson, M.L., Lim, C.H. and Zelazny, L.W., 1986. Oxides, hydroxides and aluminosilicates. In: A. Klute (Editor), Methods of Soil Analysis. Part I. Physical and Mineralogical Methods. 2nd ed. Am. Soc. Agron., Soil Sci. Soc. Am., Agronomy Series No. 9, pp. 101-150.

Jenny, H., 1980. The Soil Resource: Origin and Behaviour. Ecological Studies, 37. Springer, New York.

Kemp, R.A. and McIntosh, P.D., 1989. Genesis of a texturally banded soil in Southland, New Zealand. Geoderma, 45: 66-81.

Kern, J.P., 1977. Origin and history of upper Pleistocene marine terraces, San Diego, California. Geol. Soc. Am. Bull., 88: 1553-1566.

Kodama, H. and Ross, G.J., 1991. Tiron dissolution method used to remove and characterize inorganic components in soils. Soil Sci. Soc. Am. J., 55: 1180-1187.

Lajoie, K.R., 1986. Coastal tectonics, In: Geophysics Study Committee, Active Tectonics. Studies in Geophysics. Natl. Acad. Press, Washington, DC, pp. 95-124.

Marsh, W.M., 1990. Nourishment of perched sand dunes and the issue of erosion control in the Great Lakes. Environ. Geol. Water Sci., 16: 155-164.

Matthews, R.K., 1990. Quaternary sea-level change, In: Geophysics Study Committee, Sea-Level Change. Studies in Geophysics. National Acad. Press, Washington, DC, pp. 88-103.

McLean, E.O., 1982. Soil pH and lime requirement. In: A. Klute (Editor), Methods of Soil Analysis. Part 1. 2nd ed. Agron. Monogr. 9. ASA, Madison, WI, pp. 199-224.

Merritts, D. and Bull, W.B., 1989. Interpreting Quaternary uplift rates at the Mendocino triple junction, northern California, from uplifted marine terraces. Geology, 17: 1020-1024.

Merritts, D.J., Chadwick, O.A. and Hendricks, D.M., 1991. Rates and processes of soil evolution on uplifted marine terraces, northern California. Geoderma, 51: 241-275.

Miles, R.J. and Franzmeier, D.P., 1981. A lithochronosequence of soils formed in dune sand. Soil Sci. Soc. Am.
J., 45: 362-367. 
Moody, L.E. and Graham, R.C., 1994. Pedogenic processes in thick sand deposits on a marine terrace. In: D.L. Cremeens, R.B. Brown and J.H. Huddleston (Editors), Whole Regolith Pedology. Soil Sci. Soc. Am. Spec. Publ., 34.

Muhs, D.R., 1982. A soil chronosequence on Quaternary marine terraces, San Clemente Island, California. Geoderma, 28: 257-283.

Muhs, D.R., 1983. Quaternary sea-level events on northern San Clemente Island, California. Quat. Res., 20: 322341.

Muhs, D.R., 1992. The last interglacial-glacial transition in North America: Evidence from uranium-series dating of coastal deposits. Geol. Soc. Am. Spec. Pap., 270.

Nahon, D.B., 1991. Self-organization in chemical lateritic weathering. In: M.J. Pavich (Editor), Weathering and Soils. Geoderma, 51: 5-13.

Orme, A.R. and Tchakerian, V.P., 1986. Quaternary dunes of the Pacific coast of the Californias. In: W.G. Nickling (Editor), Aeolian Geomorphology. 17th Ann. Binghamton Geomorphology Symp. Proc., pp. 149-175.

Rhoton, F.E., Meyer, L.D. and McChesney, D.S., 1991. Depth-of-erosion assessment using iron-manganese nodule concentrations in surface horizons. Soil Sci., 152: 389-394.

Soil Conservation Service, 1984. Procedures for collecting soil samples and methods of analysis for soil survey. USDA-SCS. Soil Survey Invest. Rep. No. 1. U.S. Gov. Print. Office, Washington, DC.

Soil Survey Division Staff, 1993. Soil Survey Manual. Agric. Handbook No. 18. U.S. Gov. Print. Office, Washington, DC.

Soil Survey Staff, 1992. Keys to Soil Taxonomy. 5th ed. Soil Management Support Serv. Tech. Mon. No. 19. Pocahontas Press, Inc., Blacksburg, VA.

Torrent, J., Nettleton, W.D. and Borst, G., 1980. Clay illuviation and lamella formation in a Psammentic Haploxeralf in southern California. Soil Sci. Soc. Am. J., 44: 363-369.

Vepraskas, M.J., 1992. Redoximorphic features for identifying aquic conditions. North Carolina Agric. Res. Serv. Tech. Bull. 301, Raleigh, NC.

Woodring, W.P. and Bramlette, M.N., 1950. Geology and paleontology of the Santa Maria district, California. U.S. Geol. Surv. Prof. Pap., 222. 